\title{
Building a Travel Influencer Brand Using Instagram Tools
}

The aim of this paper is to create and present a model which suggests what and how Instagram tools should be used by a new travel influencer trademark in order to create intangible values to become a brand. The paper presents the results of research on travel influencer brands and also the results of a travel influencer trademark created by the Traveler's Child. In addition, types of visual content are introduced in order to differentiate content posted by brands and trademark. The authors include recommendations for travel influencer trademark owners on how to process through branding stages, while using Instagram tools so that to create intangible values, which would allow a trademark to become a brand.

Keywords: influencer marketing, social media, Instagram marketing, branding, travel industry, branding using social media tools, branding using Instagram tools, Instagram tools, travel influencer, travel influencer marketing, travel influencer branding.

Tyrimo tikslas - sukurti ir pristatyti modelį, j̦vardijantį, kokias „Instagram“ priemones ir kaip turètų naudoti naujai susikūręs kelionių nuomonès lyderio prekès vardas, siekdamas sukurti neapčiuopiamas vertybes, reikalingas norint tapti prekių ženklu. Darbe pristatomi tyrimų rezultatai, kuriuose analizuojamas kelionių nuomonės lyderių reiškinys, jo vartotojai ir kelionių nuomonès lyderių prekės vardas „Traveler’s Child“. Taip pat pristatomi vizualinio turinio tipai, leidžiantys išskirstyti turinị, kurị publikavo prekių ženklai, vartotojai ir prekès vardas. Darbe pristatomos rekomendacijos kelionių nuomonès lyderių prekès vardo savininkams, nurodant, kaip prekès vardui tapti prekių ženklu naudojant „Instagram“ priemones, sukuriant neapčiuopiamas vertybes. Raktiniai žodžiai: nuomonès lyderių rinkodara, socialinė medija, „Instagram“ rinkodara, prekių ženklo kūrimas, kelionių industrija.

\section{Introduction}

In the era of social media, users become equals to companies and can acquire audiences, which are big enough to generate social influence and have an impact on customers' decisions. These types of people are called social influencers and due to their significance to other consumers, they become able to create brands of their own. What is more important these social influencer brands created not by companies, but by social media users are more trusted by consumers. Statistics show that $74 \%$ of consumers rely on social media while making a purchasing decision (Bennett, 2014), and $96 \%$ of consumers, who discuss brands online, do not even follow the official social media profiles owned by those brands (Smith, 2016). Moreover,

Paulius BAKANAUSKAS - MBA from Vytautas Magnus University, graduate student of the Faculty of Economics and Management. Address: S. Daukanto str. 28, Kaunas, Lithuania. E-mail: paulius.bakanauskas@vdu.lt

Justinas KISIELIAUSKAS - PhD, Vice-dean of the Faculty of Economics and Management, Vytautas Magnus University, Lithuania. Address: S. Daukanto str. 28, LT-44248, Kaunas, Lithuania. Phone: +370 37327856. E-mail: justinas.kisieliauskas@vdu.lt 
according to Nielsen's Global Trust in Advertising Survey (2012), 92\% of people trust the recommendations of individuals (even though they do not know them personally) over brands. That is why it becomes relevant to analyse how social media users can create social influencer brands of their own.

Surprisingly, not so long ago one of the largest industries in the world - travel industry - was the second slowest industry, after financial services, to adopt Instagram, which is the second largest social media website worldwide (Jauncey, 2015). According to A. Sibley (2012), 90\% of information transmitted to the brain are visuals and it is being analysed 60 thousand times faster than textual information. Thus, it is inconceivable and a major opportunity for people to put their efforts into creating travel influencer trademarks on Instagram - a visual-based social media platform. After a trademark is established, the remaining goal is to find a way to turn into a brand, i.e., to make yourself an influencer whose opinion matters and has influence on consumer decisions.

The object of analysis: the process of creating intangible values using Instagram tools that would allow a newly created travel influencer trademark to become a brand.

The research problem defined as a question: How a newly created travel influencer trademark should exploit Instagram tools to successfully perform the branding process, which would allow to create intangible values that would enable the trademark to become a brand?

The pursued goals. To develop a model that would help a newly created travel influencer trademark to exploit Instagram tools, which through the process of branding, would allow it to become a brand. The aim will be achieved by performing qualitative analysis on different types of visual content posted by different travel influencer brands, trademark and its customers and by performing data analysis to process the findings.

\section{Theoretical background}

In 2013, T. Nistorescu and others, tackled the existing problem in the misuse of the word brand and suggesting that an image, which is yet to carry any values or power, though does identify one company from its competitors, should be called a trademark. According to experts, the trademark is an indication of a property and the brand is a relationship existing between customers and a product, service or idea. The idea of a brand is to add value to a business. G. Smith (2009) also notices the differences between these definitions. According to the author, brand is both physical and emotional switch, which creates relationships between the customer and the services or products (Smith, 2009). This comparison of definitions allows to state, that a trademark becomes a brand only when it acquires the intangible values that can influence the customer's decisions and hopes.

D. Aaker proposed the strong brand concept in 1996. The theory states that for a brand to become a strong brand, there are a number of qualities that must be applied. The ideas presented in author's work, actually interpret brand the same way as trademark was described in previous parts and strong brand idea matches the brand idea. D. Aaker (1996) also presents the foundational parts of what is a 
brand and what intangible values does it have to meet in order to be one.

After understanding that a brand is a trademark, which possesses intangible values for the customer, the further question remains - how to create these intangible values to achieve the result of your trademark becoming a brand?

The Branding Process. Z. Geller (2013) compares brand and branding by quoting K. Zhivago - "Branding is the promises you make. Your brand is the promises you keep" (Geller, 2013, p. 14).

According to D. Aaker (1996), three main themes exists when creating a brand. First, there is the strategic brand analysis, where the trends, the competitors and personal qualities are analysed. Second, there is a brand identity system and it is crucial to analyse its development possibilities. Finally, there is the brand implementation system, which is a last step when creating the brand and to see if the previous steps were successful.

In the standard D. Aaker's brand equity model, in which the author explains how it generates value, he expresses the four main assets of categories: (1) Brand awareness, (2) Brand loyalty, (3) Perceived quality, and (4) Brand associations (Aaker, 1996). In the next paragraphs, these terms will be explained.

- Brand awareness. According to D. Aaker (1996), brand awareness is the most important part of brand equity as it shows how strong the brand's presence is engraved into customer's mind. K. L. Keller (2013) believes that brand awareness shows if the consumers are familiar with the brand.

- Brand loyalty. D. Aaker (1996) believes that the brand loyalty is important, as it is what shows how valuable the brand is to customers. Customers support for the brand and their loyalty is important, as this is what helps the brand to grow. Nowadays when marketing changes its focus point from quality to experience (Klaus, Maklan, 2013) customer-organization relationship became one of the driving factors for successful brand building.

- Perceived quality. In the traditional brand concept, D. Aaker (1996) states that quality is usually the main dimension of positioning for brands to show their advantage over the competition. Though having in mind the previously mentioned statement by P. Klaus and S. Maklan (2013), it is possible to state, that brand loyalty becomes more important for brand building than the perceived quality.

- Brand associations. According to D. Aaker (1996), this is what the organization wants to stand for in costumers' mind. It is a very important factor in order to develop and establish the brand identity. C. D. Bevins (2014) says that it is important for a brand to stay loyal to their foundations to reach consistency, which is a crucial factor for success.

The findings of this chapter allow to conclude that the ideas of D. Aaker (1996) can be adapted to our firstly discovered model - brand equity assets of categories are what was previously called as intangible values.

According to K. Freberg et al. (2011), social media influencers are a new type of endorsers who are independent and shape audience attitudes through different types of media. C. Francalanci and A. Hussain (2015) explain it as the users of social media who have acquired a wide audience. 
Statistics show that $74 \%$ of consumers rely on social media while making a purchasing decision (Bennett, 2014), and $96 \%$ of consumers, who discuss brands online, do not even follow the official social media profiles owned by those brands (Smith, 2016). What is more, according to Nielsen's Global Trust in Advertising Survey (2012), 92\% of people trust the recommendations of individuals (even though they do not know them in person) over brands. That is possibly because with individuals users feel actual social presence, which happens due to intimacy, interpersonal communication (Bergström, Bäckman, 2013).

Travel Industry. According to the World Travel and Tourism Council (2016) travel and tourism has been one of the major contributors of GWP ${ }^{1}$. According to the source, in 2015 the direct contribution of this industry to GWP was more than 2 trillion U.S. dollars, which is 3\% of total GWP. The industry is directly responsible for more than 107 million jobs worldwide, which is $3.6 \%$ of total world employment. The numbers are even higher if we look at the indirect contribution. Due to the supply chain, investments, etc. travel industry is responsible for almost 8 trillion U.S. dollars, which is more than $10 \%$ of GWP.

Travel Influencer. Z. Xiang and U. Gretzel (2010) made research, where the results showed that users are more likely to use search engines before making travel decisions and that these systems usually direct users to social media sites or, in other words, to influencers. This proves that travel influencers are gaining an important role in this industry as they can be directly responsible for the decisions of other travellers. Another research made by E. Christou (2015) confirms this idea of increasing impact of travel influencers as the author says that third-party opinion makes other users increase their trust in the matter. In addition, N. Sumarian et al. (2014) say that increasing popularity of digital media leads to the fact that social media platforms like Instagram or Pinterest are the most effective in promoting tourism.

So, in this context, with the continuing growth of the impact and usage of social media, advertisers have been forced to implement effective marketing strategies in order to reach consumers on social media platforms.

The social media platform Instagram is currently one of the most popular of its kind. According to D. Chafey (2017) it has 600 million users worldwide and is the second largest social media site if excluding Chinese and messenger type of social media websites. According to the same source, Instagram has the second most loyal audience, half of which uses this social media platform every day.

Instagram gives brand owners the following main tools:

- Posting an image or a video;

- Writing a description;

- Using hashtags;

- Viewing the engagement data;

- Engaging with other users (commenting, liking posts of other users and following their accounts).

- Engaging with other trademarks or brands (receiving shout-outs or performing takeovers).

1 GWP - Gross World Product - combined gross national product of all the countries in the world. CIA World Factbook. CIA (2015). 
In addition, recently Instagram added new features, which were not actively used in the time of writing this paper, i.e. story mode and video streaming.

\section{Research methods}

Traveler's Child is an Instagram travel page, created in June of 2016. In the first half of the year, Traveler's Child managed to gather a respectable amount of 15 thousand followers and currently has more than 20 thousand followers. With an engagement rate of almost 10 percent it nearly doubles the engagement rate of an average Instagram influencer, which is 3-6 percent (FanBridge, 2015).

During the research period, Traveler's Child managed to create contact with a couple of tourism departments in Kaunas (Lithuania) and Gent (Belgium). According to Instagram data, $68 \%$ of the Traveler's Child's audience is women and 32\% men. The biggest age groups are people of 18-24 and 25-34 years. The majority of followers come from the United States of America and Turkey. The Traveler's Child travel influencer trademark is oriented to create trust and relationship with their customers in order to become more influent. The communication occurs on different social media channels, but mainly on Instagram, so it is most relevant social media channel for the research. Research will analyse this trademark's Instagram social media account: user engagement and the content type.

Research logic. For the purpose to research the problem, the case analysis strategy was chosen using qualitative content analysis and data analysis.
The research problem. How a newly created travel influencer trademark should exploit Instagram tools to successfully perform the branding process, which would allow to create intangible values that would enable the trademark to become a brand?

The objective of research. To develop a model that would help a newly created travel influencer trademark exploit Instagram tools, which through the process of branding, would allow it to become a brand.

The research goals. By using qualitative content analysis to go through branding processes, namely: strategic brand analysis; brand identity system; brand identity implementation system, which would include analysing the content of Traveler's Child, competitors and customers.

\section{Research results}

The analysis enabled the authors to present a full model of the D. Aaker's traditional branding model adaptation to the case of travel influencer branding using Instagram tools. The model represents the findings of this paper on how a travel influencer trademark should exploit Instagram given tools in order to create intangible values to become a brand.

First, during the brand analysis stage the following findings were formed:

- Both competitor and customer analysis are recommended;

- However, customer analysis provides data, which is closer to the actual results of trademark performance.

- Brand analysis allows to proceed towards the next stage, which is the 
brand identity system and is crucial for setting the intangible values, which a trademark has to create for its customers.

Second, during the brand identity system stage these findings were formed:

- Brand identity system stage should rely on the findings of brand analysis stage.

- To create brand awareness a trademark has to position itself as a person, which allows for the customer to create a deeper bond and feel closer to the trademark. This is achieved through Instagram tools like post descriptions, while expressing feelings, emotions and experiences.

- To create brand associations a trademark should acquire social values, by which they stand and communicate it through post descriptions. In addition, using post descriptions is a tool, which should be exploited to not only show the values a trademark stands for, but to also form a deeper connection. As trademark should be presented as a person, that person should also have a character, with whom followers can associate with.

- To create perceived quality a trademark should increase the trust of its followers, as it is a long process, it can be boosted by acquiring relationships with brands, who have already gained the trust of the followers. During the theoretical analysis, the co-operation with other brands was not identified as an Instagram tool, but it was found to be a very important and useful asset to create brand credibility. Co-operation can be achieved through:

- Shout-Outs. Which is a popular way for brands and trademarks to gain followers and shout-outs are even being sold. This is because a shout-out itself is usually beneficial only for one of the sides, thus to become beneficial for both sides shout-outs become paid.

- Takeovers. Not as popular but is beneficial for both sides. One side gets the attention, while other side can save resources required for content creation.

- To create brand loyalty in a traditional model D. Aaker (1996) suggested implementing brand-customer relationship. The findings of this paper suggest, that in social media era this should transform into brand cocreation. This is because social media makes the trademark and its customer (follower) become equal. The most important factor for a trademark to grow into brand is for its content to become viral and this can only be achieved if there are customers, who are willing to constantly engage with your content. To achieve the results it is recommended to:

- Post constant type of visual content. This is the recommended way of using content posting tool. Results showed that followers most successfully engage with the content, which is the majority of posts made by the trademark or brand. This is due to the fact that those who follow you, most probably did that because of the content they liked and they expect more of the same.

- Constantly use the tools to engage with the followers (commenting, liking posts of other users and following their accounts). The 
connection has to be mutual and if the followers are commenting and liking pictures of the trademark, he or she expects you to return the favour, because as mentioned before social media makes the trademark and the customer equal. In addition, if trademark possesses itself as a person, creating relationships is also a thing to do.

Finally, during the brand identity implementation system stage the authors have formed these recommendations:

- Brand positioning should rely on the decided strategy of the brand identity system stage.
- During the execution these factors there should be used and/or tested:

- Positioning values. The authors believe that positioning values, could be beneficial for creating deeper brand associations.

- Post descriptions. The experiences gained during the research period allows stating that a post descriptions tool should be beneficial for creating both intangible values of brand awareness and brand associations. The authors also suggest the following categorization of post descriptions: historical; experiential; informational;

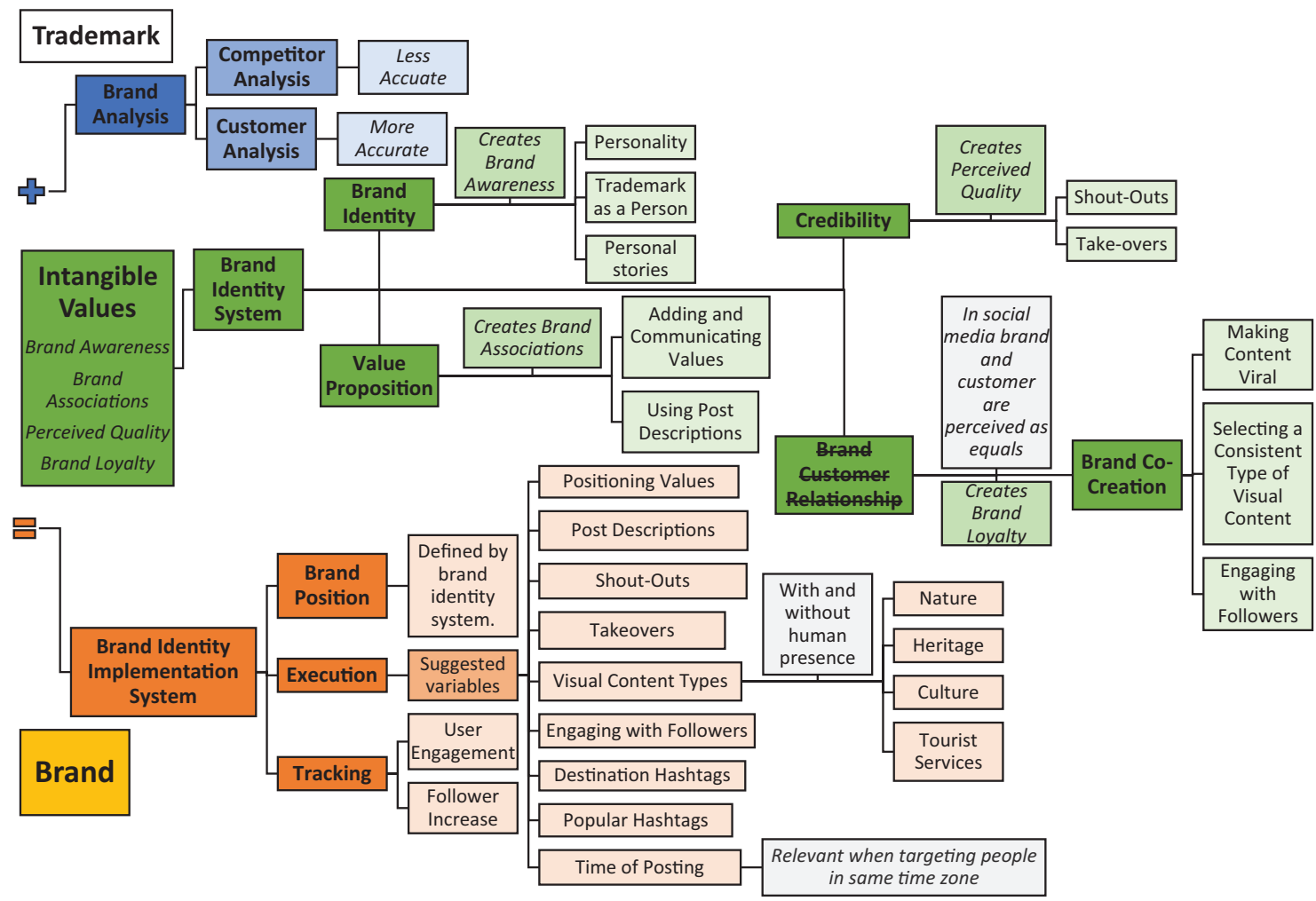

Fig. 1. D. Aaker's traditional branding model (1996) adaptation to the case of travel influencer branding using Instagram tools. 
promotional; resonant; non-related; no description.

- Shout-outs. Receiving shout-outs increases trademark's visibility, benefits the perceived quality and credibility.

- Takeovers. Performing successful takeovers increases the trademark's visibility, benefits the perceived quality and credibility.

- Visual content types. The results of this paper showed that different visual content types have different results on engagement. It is recommended to check, which of them are the most effective in different cases of travel influencer trademarks or brands. Visual content types suggested by J. A. Donaire et al. (2014) proved to be effective when categorizing travel related images.

- Engaging with customers. This tool is one of the most important and it is recommended not to ignore it. There is a huge difference in both follower engagement and follower increase when this tool is being used and not.

- Destination hashtags. This tool is also recommended as it attracts the people who are interested in these destinations, so your content becomes more relevant and there is a higher chance of user engagement.

- Popular hashtags. Despite checking the difference between different hashtag usage, authors believe that it is recommended to use popular hashtags, which are relevant to your content as it increases the chances of user engagement.
- Time of posting. This variable was not significant for the research of this thesis as Traveler's Child has acquired audience from different parts of the world, from different time zone. However, in case of target group being in the same time zone this factor is recommended to be taken into account.

\section{Conclusions}

In the era of social media, an opportunity for users to become influencers arises. This is because social media platforms allow user created content to be in close reach for other users. As travel industry is one of the largest industries in the world and not yet well adapted by the second largest social media platform - Instagram - an opportunity for ordinary people appears. Therefore, it is necessary to analyse how people can adapt traditional branding process created by D. Aaker (1996) using Instagram to create their own travel influencer brands and generate income from their influence. In the theoretical part, the following conclusions have been made:

1. A trademark is a sign or a symbol, which differentiates one service provider from another. A brand is a sign or a symbol, which user identifies with certain experiences and intangible values (Nistorescu et al., 2013). In the case of social media, a travel influencer trademark is what differentiates one social media user, who has a goal to become an influencer from another, while the travel influencer brand identifies social media user, who has created intangible values in consumers mind and generates influence - has an impact on consumer decisions. 
2. Social media users become able to generate influence due to the crowdculture phenomenon (Holt, 2016) - users are no longer only on the receiving end but can transmit their message too and be widely heard.

3. Social media platform types and the importance of visual communication has been highlighted. That also allowed to understand why Instagram, which is an image-sharing based social media platform should be emphasized by the scholars.

The analysis showed the process of how the final model of travel influencer branding using Instagram tools can be formed. The following additional conclusions and recommendations were made:

4. Consistency has more impact on the trademarks' success and not the particular types of visual content.

5. Positioning a trademark when a person allows creating a more successful brand identity is more effective when creating brand awareness.

6. Associating the trademark with some social values and communicating through post descriptions allows effectively creating associations in consumers' mind.

7. Shout-outs and takeovers create perceived quality and makes the trademark look more credible.

8. Brand-customer relationship due to social media era tendencies should be replaced by brand co-creation.

9. Brand co-creation allows trademarks' content to get viral, which is the crucial part for a trademark to grow. From a brands' perspective, a more involved audience can be achieved by publishing consistent content and active engagement with the followers.
10. Despite Instagram being an imagesharing social media platform, trademark owners should emphasize the importance on the textual part of the post publishing, as descriptions prove to have importance in user engagement.

11. The following possible variations of the Instagram tools usage were identified:

a. Value positioning;

b. Visual content types;

c. Post descriptions;

d. Post time;

e. Destination hashtags;

f. Popular hashtags;

g. Engaging with other trademarks or brands:

i. Shout-outs;

ii. Takeovers;

h. Engaging with followers.

This paper analysed different types of the usage of Instagram tools for travel influencer brands and trademarks. Depending on the findings of this paper, future researchers would be able to introduce the concepts of trademark, brand, branding, social media, challenges in social media era, Instagram, travel industry and travel influencer phenomenon. As Instagram remains a fast growing social media platform and the travel influencer phenomenon is still not well researched this is where the research novelty is revealed.

Scholars should be able to obtain information how to interpret the visual travel related data on Instagram and how the tools provided by this social media platform transfers into branding process. Depending on this research, future researchers should be able to adapt this information to other social media platforms and to different industries. 
This research contained a number of limitations, which could be analysed in the future:

1. The impact of posting time was not analysed, because this information is hardly obtainable on Instagram in competitors' and customers' cases (only the day of posting is provided), there was no way to track the time of posting. In addition, as for a trademark created for the purposes of this paper - Traveler's Child there was no target audience, so due to different time zones, this type of analysis seemed irrelevant. Further research could analyse different social media platforms, which provide a precise time of posting to see if there is an effect of posting at the same time as competitors and customers.

2. The impact of popular hashtags was not analysed. The authors of this paper have decided not to add another qualitative variable in the research as there were already plenty of them. As the research revealed, too many qualitative variables make difficult to predict which of the variables had the effect. In the future, researchers could base their research on using the pictures of the same visual type, as well as, from the same city, with the same destination hashtags, to see the impact of different popular hashtags. Accounts of particular destinations (for example: visit_kaunas, topamsterdamphoto, etc.) are popular on Instagram and would allow to contain constant qualitative variables and to check the impact of variables not analysed in this paper.

3. The impact of post descriptions was not analysed. The authors of this paper presumed that because Instagram is an image-sharing social media platform there is only a need to analyse the visual aspects of content sharing. During the research an effect of different types of descriptions was noticed, which allows to presume that there is an actual impact of post descriptions. Further research could analyse how user engagement is affected by this qualitative variable. The authors of this paper suggest these types of post descriptions:

a. Historical - describing the history of the object seen in the image.

b. Experiential - describing the experience a person had with object or place seen in the image.

c. Informational - giving information and advices for people who might visit the place seen in the image.

d. Promotional - promoting the object seen in the image for financial purposes, contests.

e. Resonant - writing posts that are related to events happening in the follower's life, i.e., worldwide events, celebrations, etc.

f. Non-related - describing other things, which are not related to the object seen in the image.

g. No description. 


\section{References}

1. Aaker, D. (1996). Building Strong Brands. New York: The Free Press.

2. Bennett, S. (April 25 $5^{\text {th }}, 2014$ ). Social Media Business Statistics, Facts, Figures \& Trends 2014. Adweek. Internet access: http://www. adweek.com/socialtimes/social-businesstrends-2014/498129 [accessed April 11, 2017].

3. Bergström, T., Bäckman, L. (2013). Marketing and PR in Social Media. - Stockholm: Stockholms universitet.

4. Bevins, C. D. (2014). A Visual Social Semiotic Analysis of Target's Branding Using Instagram: Master's Thesis. - Faculty of Liberty University School of Communication Studies.

5. Chafey, D. (2017). Global Social Media Research Summary 2017. SmartInsights. Internet access: http://www.smartinsights.com/social-mediamarketing/social-media-strategy/new-globalsocial-media-research/ [accessed May 1, 2017].

6. Christou, E. (2015). Branding Social Media in the Travel Industry // Procedia - Social and Behavioral Sciences. Vol. 175, pp. 607-614. doi: 10.1016/j.sbspro.2015.01.1244

7. CIA World Factbook. CIA (2015). Internet access: https://www.cia.gov/library/publications/ download/download-2015/index.html

8. Donaire, J. A., Camprubí, R., Galí, N. (2014). Tourist Clusters from Flickr Travel Photography. Faculty of Tourism - University of Girona.

9. Fan Bridge (2015). What is a Good Engagement Rate? (May 15 $\left.5^{\text {th }}, 2015\right)$. Internet access: https:// www.fanbridge.com/blog/what-is-a-goodengagement-rate\#.WPkSZGmGOUk [accessed April 11, 2017].

10. Francalanci, C., Hussain, A. (2015). Discovering Social Influencers with Network Visualization: Evidence from the Tourism Domain. - Berlin, Heidelberg: Springer - Verlag.

11. Freberg, K., Graham, K., McGaughey, K, Freverg, L. A. (2011). Who are the Social Media Influencers? A Study of Public Perceptions of Personality // Public Relations Review. Vol. 37, pp. 90-92. Internet access: https://www.researchgate.net/profile/Laura Freberg/publication/251582746_Who_are_ the_social_media_influencers_A_study_ of_public_perceptions_of_personality/ links/0a 85e536857cdb90d6000000.pdf. doi:10.1016/j.pubrev.2010.11.001 [accessed March 22, 2017].
12. Geller, Z. (2013). Branding for Bloggers. - New York: Allworth Press.

13. Holt, D. (2016). Branding in the Age of SoMedia. Harvard Business Review. 94(3), 40-50.

14. Jauncey, J. [Skift] (November, 19 ${ }^{\text {th }}, 2015$ ). Beautiful Destinations Founder at Skift Global Forum. [Video File]. Internet access: https:// www.youtube.com/watch?v=C1aX_BeVDxw [accessed May 2, 2017].

15. Keller, K. L. (2013). Strategic Brand Management: Building, Measuring and Managing Brand Equity. 4th edition. - Harlow, UK: Pearson Education Limited.

16. Klaus, P., Maklan, S. (2013). Towards a Better Measure of Customer Experience // International Journal of Market Research. Vol. 55, No. 2, pp. 227-246. 2017. Internet access: http://dx.doi.org/10.2501/IJMR-2013021 [accessed March 9, 2017].

17. Nielsen's Global Trust in Advertising Survey. (October $4^{\text {th }}, 2012$ ). Internet access: http://www. nielsen.com/us/en/press-room/2012/nielsenglobal-consumers-trust-in-earned-advertisinggrows.html [accessed April 11, 2017].

18. Nistorescu, T., Barbu, C., Dumitriu, R. (2013). Trademark vs Brand: A Conceptual Approach // Management \& Marketing. 2013, Vol. 11, No. 1, pp. 29-37.

19. Sibley, A. (2012). 19 reasons you should include visual content in your marketing data. Hubspot. Internet access: http://blog.hubspot.com/blog/ tabid/6307/bid/33423/19-Reasons-You-ShouldInclude-Visual-Content-in-Your-MarketingData.aspx [accessed April 11, 2017].

20. Smith, K. (March $7^{\text {th }}$, 2016). Marketing: 96 Amazing Social Media Statistics and Facts. Brandwatch.com. Internet access: https://www. brandwatch.com/blog/96-amazing-socialmedia-statistics-and-facts-for-2016/ [accessed April 11, 2017].

21. Sumarian, N., Zahari, M. S., Radzi, S. M., Mohi, Z., Hanafiah, M. H., Bakhtiar, M. F., Zainal, A. (2014). Hospitality and Tourism: Synergizing Creativity and Innovation in Research. - Boca Raton: CRC Press Taylor \& Francis Group.

22. Xiang, Z., Gretzel, U. (2010). Role of Social Media in Online Travel Information Search // Tourism Management. Vol. 31, No. 2, pp. 179188. doi:10.1016/j.tourman.2009.02.016.

The paper submitted: October 9, 2018

Prepared for publication: December 10, 2018 
Paulius BAKANAUSKAS, Justinas KISIELIAUSKAS

\section{KELIONIŲ NUOMONĖS LYDERIO PREKIŲ ŽENKLO KŪRIMAS NAUDOJANT „INSTAGRAM“ SOCIALINI TINKLA}

\section{S a n t r a u k}

Tyrimas buvo atliekamas 2016 m., naudojantis tuometinemis „Instagram“ socialinio tinklo teikiamomis priemonemis socialinių tinklų nuomonès lyderio prekių ženklui kelionių industrijoje kurti.

Tyrimo tikslas - sukurti ir pristatyti modelį, ivvardijantį, kokias „Instagram“ priemones ir kaip turètų naudoti naujai susikūręs kelionių nuomonès lyderio prekès vardas, siekdamas sukurti neapčiuopiamas vertybes, reikalingas norint tapti prekių ženklu. Darbe atliekama literatūros analizè, kurios metu, remiantis vietinių ir užsienio autorių publikacijomis, išskiriama: skirtumai tarp prekès vardo ir prekių ženklo; prekių ženklo kūrimas; socialinès medijos ir „Instagram“; kelionių industrijos fenomenas. Tyrimo pamatinè teorija - D. Aakerio (1996) sukurta prekių ženklo kūrimo metodika. Autorių teigimu, tyrimas yra aktualus dèl to, kad gali padèti socialinių tinklų pavieniams asmenims igyti pakankamai vartotojų nuomonei reikšmingos itakos, leidžiančios jiems konkuruoti su įmonemis. Siekiama sukurti modelị, nurodantị, kokios „Instagram“ priemonès leidžia atlikti D. Aakerio sukurtoje teorijoje išdèstytus veiksmus, padèsiančius paprastiems vartotojams kurti savo prekių ženklą.

Su naujai sukurtu socialinių tinklų nuomonès lyderio prekès vardu yra dirbama pagal visus esminius D. Aakerio išskirtus metodus ir taikomas situacijos analizès metodas. Atliekama prekès vardo aplinkos bei vidiné analizè, nagrinejjamos vystymosi galimybès bei igyvendinama prekès vardo strategija. Remiantis to paties autoriaus teorija, kuriamos keturios esminès neapčiuopiamos vertybès - prekių ženklo žinomumas, ištikimybè prekių ženklui, įsi- vaizduojamoji prekių ženklo vertè bei asociacijos su prekių ženklu.

Tiriamojoje darbo dalyje pristatomi tyrimų rezultatai, kuriuose analizuojami žymūs kelionių nuomonès lyderių prekių ženklai, jų vartotojai ir tyrëjų sukurtas kelionių nuomonès lyderių prekès vardas „Traveler's Child“. Išskiriami kokybiniai rodikliai, kurie leidžia analizuoti, kaip ìvairios jų variacijos paveikia sekejų elgseną. Tyrime pristatomi vizualinio turinio tipai, leidžiantys skirstyti ir analizuoti turinį, kurị publikavo prekių ženklai, vartotojai ir prekès vardas. Daroma prielaida, kad skirtingi vizualinio turinio tipai gali lemti didesnę ar mažesnę prekès vardo ar prekių ženklo publikuotos žinutès sèkmę bei augimą. Taip pat išskiriami pagrindiniai kintamieji, kurie gali lemti žinutès sèkmę socialiniame tinkle „Instagram“ ir kaip šie kintamieji gali būti pritaikomi naudojant klasikinị D. Aakerio prekių ženklo kūrimo modelį. Paskutinèje dalyje pristatomos rekomendacijos kelionių nuomonès lyderių prekès vardo savininkams, siekiantiems sukurti prekių ženklą. Jose nurodoma, kaip „Instagram“ priemonès gali prisidèti prie neapčiuopiamų vertybių sukūrimo.

Tyrimo rezultatai atskleidžia, kad „Instagram“ socialinis tinklas suteikia visas reikalingas priemones, norint sẻkmingai kurti prekių ženklą tinkamai adaptuojant tradicines rinkodaros teorijas bei metodus. Tradiciné D. Aakerio teorija taip pat yra papildoma naujomis teorijomis, kurias lemia tai, kad socialiniuose tinkluose prekių ženklo kūrimas tampa tiek jo savininko, tiek jo klientų bendru aktyvumo rezultatu. 